| JURNAL PETERNAKAN | VOLUME : 03 | NO : 02 | TAHUN 2019 | E-ISSN. 2599-1736|69

\title{
Effect Of Long Thawing On The Quality Of Frozen Cow Brahman Cattle
}

\author{
Ririn Novita ${ }^{1}$, Hayatun Nofrida ${ }^{1}$, Sri Lestari $^{1}$ \\ ${ }^{1}$ Dosen Prodi Peternakan Fakultas Pertanian Universitas Musi Rawas Jl. Sultan Mahmud \\ Badaruddin II Kel. Air Kuti I, Lubuklinggau-31628 Email : novitaririn91@yahoo.com
}

\begin{abstract}
This study purposed is to determine the effect of thawing duration toward the quality of Brahman frozen semen. These include the motility of Spermatozoa, Spermatozoa concentration, Percentage of Spermatozoa Viability, Percentage of Spermatozoa Abnormalization and Individual Moitility, which was conducted at the UPTD Balai Artificial Insemination (BIB) Sembawa, Banyuasin District, South Sumatra Province. This research is experimental and carried out a non-factorial complete random design analysis (CRD) consisting of 6 levels of treatment and 4 repetitions so that 24 unit experiments are be obtained, through variations in the treatment of 10, 20,30, 40, 50, and 60 seconds, the length of time thawing. The effect of frozen thawing semen for Brahman Cattle has a very significant effect on Individual Motility and Percentage of Viability of Spermatozoa. Thawing time of 30 seconds on T3 treatment gives a very good influence on the quality of frozen semen of Brahman Cows, while on thawing time of 50 seconds on T5 treatment gives good quality on the percentage of spermatozoa abnormalities. The frozen semen spermatozoa concentration value of Brahman cattle is $53 \times 10^{6}$
\end{abstract}

Keywords: quality of frozen semen, thawing duration, Brahman cattle

\section{PENDAHULUAN}

Ternak sapi potong di Indonesia membutuhkan perhatian khusus dalam kaitannya dengan upaya mempertahankan dan menunjang peningkatan populasi ternak. Kementerian Pertanian Republik Indonesia telah mencanangkan program swasembada daging sapi tahun 2014 untuk mendukung program ketahanan pangan dan program diversifikasi pangan nasional. Langkah langkah strategis yang ditempuh dalam program swasembada tersebut salah satunya adalah dengan mengoptimalisasikan pelaksanaan inseminasi buatan (IB). Pelaksanaan kegiatan inseminasi buatan pada ternak merupakan salah satu upaya penerapan teknologi tepat guna yang merupakan pilihan utama untuk peningkatan populasi dan mutu genetik sapi. Keberhasilan inseminasi buatan pada ternak sapi telah mencapai 2.116.159 akseptor dengan kelahiran 1.333.075 ekor pada tahun 2009. Inseminasi buatan adalah salah satu teknik yang dikembangkan 
untuk meningkatkan populasi ternak, dan inseminasi buatan juga mencegah penularan penyakit kelamin yang mungkin terjadi dalam perkawinan alami (Said et al, 2004).

Sapi potong merupakan salah satu ternak yang dapat diandalkan sebagai penyedia daging. Hal ini tentunya merupakan hal yang sangat menguntungkan bagi peternak apabila bisa memanfaatkan peluang ini dengan baik. Selain itu, pemenuhan protein hewani bisa meningkatkan kebutuhan gizi masyarakat untuk meningkatkan kecerdasan. Upaya meningkatkan konsumsi protein hewani bagi masyarakat berarti juga harus meningkatkan produksi bahan pangan asal ternak. Pada akhirnya, hal tersebut berarti upaya peningkatan produksi ternak (Rianto, 2009).

Usaha ternak sapi potong di Indonesia membutuhkan perhatian khusus dalam kaitannya dengan upaya mempertahankan dan menunjang peningkatan populasi ternak. Guna peningkatan populasi tersebut maka dilakukan pemanfaatan teknologi reproduksi peternakan melalui teknik Inseminasi Buatan (IB) dengan menggunakan semen beku (Kaiin et al, 2005).

Sejak diperkenalkannya Inseminasi Buatan (IB) pada hewan, para ilmuwan mulai mencurahkan perhatian pada peningkatan produksi ternak melalui Ineminasi Buatan. Teknologi tersebut pada awalnya dimanfaatkan pada peternak sapi perah, namun kini telah meluas penggunaannya pada sapi pedaging, kambing, kuda, babi, anjing, dan kucing (Sulabda dan Puja, 2010).

Inseminasi buatan merupakan suatu cara perkawinan yang lebih efisien dan efektif dalam penggunaan semen pejantan unggul untuk membuahi sapi betina dalam jumlah banyak dibandingkan dengan perkawinan alam. Salah satu faktor yang mempengaruhi keberhasilan Inseminasi Buatan adalah kualitas semen pejantan unggul yakni karakteristik semen yang dapat dinilai melalui pemeriksaan secara makroskopis maupun mikroskopis (Sumeidiana, 2007).

Proses thawing harus dilakukan dengan waktu yang singkat untuk menghindari kerusakan sel yang disebabkan oleh rekristalisasi. Mitokondria yang rusak akan menyebabkan putusnya rantai oksidasi. Akibatnya, pergerakan spermatozoa terhenti karena tidak ada lagi pasokan energi dari organel mitokondria yang berfungsi merangsang fungsi mikrotubula (Gazali dan Tambing, 2002). Pramunico (2003) menyatakan bahwa suhu thawing yang rendah akan menghasilkan angka motilitas yang lebih rendah begitu juga sebaliknya suhu thawing yang tinggi maka akan menghasilkan angka motilitas yang tinggi. 
Menurut Rodriguez et al (2005), menyatakan bahwa proses thawing pada semen beku sapi dengan suhu $37^{\circ} \mathrm{C}$ selama 60 detik menyebabkan terjadinya beberapa kerusakan pada membran spermatozoa. Inseminasi Buatan komersil pada sapi sebaiknya thawing dilakukan pada suhu $37^{\circ} \mathrm{C}$ selama 20 detik karena lebih praktis serta semen beku tidak boleh di thawing di bawah suhu $15^{\circ} \mathrm{C}$.

\section{METODE PENELITIAN}

Penelitian ini telah dilaksanakan di UPTD Balai Inseminasi Buatan (BIB) Sembawa, Kabupaten Banyuasin, Provinsi Sumatera Selatan.

\section{Bahan dan Alat}

Adapun bahan yang digunakan dalam penelitian ini adalah Semen sapi Brahman, Eosin, Air, N2 Cair, $\mathrm{NaCl}$, Aquades. Sedangkan alat yang digunakan dalam penelitian adalah : stopwatch/Timer, Gunting, Gelas, Watterbad, Container, Straw, Pipet ukur, Pinset, Mikroskop, Tv monitor, Objek glass, Cover glass, Mangkok, Tisu, Camber, Micropipett, Kamera, Mistar, Alat tulis dan Kertas Label.

\section{Metode Penelitian}

Metode penelitian yang digunakan adalah metode eksperimental dengan menggunakan Rancangan Acak Lengkap (RAL) non-faktorial menggunakan 6 taraf dengan 4 kali ulangan sehingga diperoleh 24 unit percobaan, setiap unit percobaan (tiap unit) di ulang 4 kali. Adapun taraf perlakuaan yang akan di ujicobakan sebagai berikut :

$$
\begin{aligned}
& \text { T1 }=10 \text { Detik } \\
& \text { T2 }=20 \text { Detik } \\
& \text { T3 }=30 \text { Detik } \\
& \text { T4 }=40 \text { Detik } \\
& \text { T5 }=50 \text { Detik } \\
& \text { T6 }=60 \text { Detik }
\end{aligned}
$$

\section{Cara Kerja}

Cara kerja yang dilakukan dalam penelitian ini sesuai dengan thawing di UPTD Balai Inseminasi Buatan Sembawa, 2002. 


\section{Parameter Yang Diamati}

Adapun Variabel yang diamati dalam penelitian ini adalah Motilitas Masssa Spermatozoa, Motilitas Individu Spermatozoa, Persentase Viabilitas Spermatozoa, Abnormalitas Spermatozoa, dan Konsentasi spermatozoa

\section{HASIL DAN PEMBAHASAN}

Hasil analisis Pengaruh Lama Waktu Thawing terhadap Kualitas Semen Beku Sapi Brahman di sajikan pada tabel 1:

Tabel 1. Hasil analisis ragam Pengaruh Lama Waktu Thawing terhadap Kualitas Semen Beku Sapi Brahman

\begin{tabular}{clcc}
\hline No & \multicolumn{1}{c}{ Peubah yang di amati } & P & KK(\%) \\
\hline 1 & Motilitas individu & $7,20^{* *}$ & 21,04 \\
2 & Persentase hidup spermatozoa & $10,63^{* *}$ & 6,22 \\
3 & Persentase abnormal spermatozoa & $0,48^{\text {tn }}$ & 28,61 \\
\hline
\end{tabular}

Keterangan :

** : Berpengaruh Sangat Nyata

* : Berpengaruh Nyata

tn : Berpengruh Tidak Nyata

KK : Koefisien Keragaman

Tabel 2. Pengaruh Lama Waktu Thawing terhadap Kualitas Semen Beku Sapi Brahman

\begin{tabular}{llc}
\hline No & \multicolumn{1}{c}{ Peubah yang diamati } & P \\
\hline 1 & Motilitas massa & +++ \\
2 & Konsentrasi & $53 \times 10^{6}$ \\
\hline
\end{tabular}

Keterangan :

+++ : Nilai Sangat Baik

Hasil uji BNJ dan data tabulasi Pengaruh Lama Waktu Thawing terhadap Kualitas Semen Beku Sapi Brahman terhadap semua peubah yang di amati berpengaruh nyata seperti tetara pada tabel 3. 
| JURNAL PETERNAKAN | VOLUME : 03 | NO : 02 | TAHUN 2019 | E-ISSN. 2599-1736|70

Tabel 3. Hasil uji BNJ dan data tabulasi Pengaruh Lama Waktu Thawing terhadap Kualitas Semen Beku Sapi Brahman terhadap peubah yang diamati

\begin{tabular}{|c|c|c|c|c|c|c|c|c|c|}
\hline \multirow[t]{2}{*}{ No } & \multirow[t]{2}{*}{$\begin{array}{l}\text { Peubah } \\
\text { yang diamati }\end{array}$} & \multicolumn{6}{|c|}{$\begin{array}{c}\text { Lama Waktu Thawing terhadap Kualitas Semen } \\
\text { Beku Sapi Brahman }\end{array}$} & \multicolumn{2}{|c|}{ BNJ } \\
\hline & & $\mathrm{T} 1$ & $\mathrm{~T} 2$ & T3 & $\mathrm{T} 4$ & T5 & T6 & $5 \%$ & $1 \%$ \\
\hline 1 & $\begin{array}{l}\text { Motilitas } \\
\text { individu }\end{array}$ & $17,50^{\mathrm{aA}}$ & $23,13^{\mathrm{aA}}$ & $36,88^{\mathrm{bcAB}}$ & $33,75^{\mathrm{abAB}}$ & $30,63^{\mathrm{abA}}$ & $21,25^{\mathrm{aA}}$ & 12,84 & 16,02 \\
\hline 2 & $\begin{array}{l}\text { Viabilitas } \\
\text { spermatozoa }\end{array}$ & $64,38^{\mathrm{Aa}}$ & $74,25^{\mathrm{aA}}$ & $84,50^{\mathrm{abAB}}$ & $80,88^{\mathrm{abAB}}$ & $75,13^{\mathrm{abA}}$ & $68,00^{\mathrm{aA}}$ & 10,42 & 12,99 \\
\hline 3 & $\begin{array}{l}\text { Persentase } \\
\text { abnormalitas } \\
\text { spermatozoa }\end{array}$ & 9,75 & 9,75 & 9,75 & 9,13 & 8,00 & 10,88 & - & - \\
\hline
\end{tabular}

Keterangan : Angka-angka yang di ikuti huruf yang sama pada kolom yang sama berarti berbeda nyata pada taraf uji $5 \%$ dan $1 \%$.

Tabel 4. Tabel Rata-rata Lama Waktu Thawing terhadap Kualitas Semen Beku Sapi Brahman terhadap peubah yang diamati

\begin{tabular}{|c|c|c|c|c|c|c|c|}
\hline No & Peubah yang & & & ama Wa & Thawin & & \\
\hline \multirow[t]{2}{*}{1} & \multirow[t]{2}{*}{ Motilitas Massa } & T1 & $\mathrm{T} 2$ & T3 & $\mathrm{T} 4$ & T5 & T6 \\
\hline & & + & + & ++ & +++ & ++ & + \\
\hline 5 & $\begin{array}{l}\text { Konsentrasi } \\
\text { Spermatozoa }\end{array}$ & $53 \times 10^{6}$ & $53 \times 10^{6}$ & $53 \times 10^{6}$ & $53 \times 10^{6}$ & $53 \times 10^{6}$ & $53 \times 10^{6}$ \\
\hline
\end{tabular}

\section{PEMBAHASAN}

Pada penelitian ini semen beku yang digunakan adalah semen beku dari sapi Brahman. Penelitian ini dilakukan karena banyak pendapat mengenai lama waktu thawing yang dilakukan oleh inseminator dilapangan sebelum melakukan Inseminasi Buatan. Lama waktu thawing sangat berpengaruh besar terhadap keutuhan spermatozoa dalam semen, sebab selama ini banyak beberapa pendapat tentang lama waktu thawing pada semen beku yang akan digunakan dalam pelaksanaan Inseminasi Buatan maka dari itu untuk mengetahui kualitas spermatozoa yang paling optimal yang akan digunakan dalam pelaksanaan Inseminasi Buatan adalah dengan membandingkan penggunaan lama waktu thawing.

Kualitas semen di Balai Inseminasi Buatan Sembawa menggunakan tris kuning telur sebagai bahan pengencer, tris kuning telur tersebut dapat memberikan kualitas yang baik dalam spermatozoa, dapat melindungi spermatozoa selama proses pendinginan dan pembekuan. 
Komposisi kuning telur terdiri dari air, protein, lemak, karbohidrat, mineral dan vitamin (Sarwono, 1998).

Semen beku sapi merupakan semen yang berasal dari pejantan sapi terpilih yang diencerkan sesuai prosedur proses produksi sehingga menjadi semen beku dan disimpan dalam rendaman nitrogen cair pada suhu $-196^{\circ} \mathrm{C}$ pada kontainer (SNI, 2005). Pada penelitian ini semen beku yang digunakan adalah semen beku dari sapi Brahman. Semen beku yang diproduksi memenuhi syarat yaitu semen beku sapi dikemas dalam bentuk straw dengan ukuran ministraw volume 0,25 ml dengan jumlah sel spermatozoa minimal 25 juta (SNI, 2008).

Penelitian terdahulu pada sapi Simmental yang terbaik yaitu pada lama waktu 40 detik pada motilitas individu, viabilitas spermatozoa dan konsentrasi spermatozoa $64 \times 10^{6}$. Jenis bangsa sapi mempengaruhi lama waktu thawing, pada sapi Brahman lama waktu thawing terbaik yaitu 30 detik, sedangkan pada sapi Simmental 40 detik.

Faktor-faktor yang mempengaruhi kualitas semen yaitu suhu, lingkungan, umur ternak, bangsa ternak, libido dan frekuensi ejakulasi (Hafez, 2000). Berdasarkan penelitian yang di lakukan bahwa lama waktu thawing 30 detik dapat memberikan hasil yang lebih baik terhadap kualitas semen beku sapi Brahman, sedangkan lama waktu thawing 10 detik memberikan kualitas yang tidak baik terhadap kualitas semen beku sapi Brahman. Sesuai dengan pendapat Adikarta dan Listiana (2001), menyatakan bahwa lama thawing 30 detik memberikan hasil lebih baik terhadap persentase spermatozoa hidup dari pada thawing selama 15 detik. Menurut Rodriguez et.al (2005), menyatakan bahwa proses thawing pada semen beku sapi dengan suhu $37^{\circ} \mathrm{C}$ selama 60 detik menyebabkan terjadinya beberapa kerusakan pada membran spermatozoa, lama waktu thawing yang terlalu cepat dan lama dapat menyebabkan persentase spermatozoa rusak atau menyebabkan kematian.

\section{Motilitas Massa Spermatozoa Semen Beku Setelah Thawing}

Berdasarkan hasil penelitian pada motilitas massa spermatozoa di dapat nilai (+++) atau nilai sangat baik pada perlakuan T4 dengan lama waktu thawing 40 detik. Hasil penelitian menunjukan bahwa dengan suhu $37^{\circ} \mathrm{C}$ dan lama waktu thawing 40 detik ini menunjukan bahwa motilitas massa spermatozoa memiliki kualitas semen yang sangat baik(+++). Hal ini sesuai dengan pendapat Ismaya (2004), menyatakan bahwa pengamatan motilitas massa dengan suhu $37^{\circ} \mathrm{C}$ dan lama waktu thawing 30 detik memberikan kualitas spermatozoa dengan nilai sangat baik (+++), proses thawing dengan waktu yang terlalu cepat dapat menyebabkan kualitas 
spermatozoa lebih banyak tidak bergerak maupun bergerak mundur, sedangkan dengan lama waktu thawing yang terlalu lama dapat menyebabkan kematian pada spermatozoa, sperma tidak bergerak dan diam di tempat.

Menurut pendapat Feradis (2010), menyatakan bahwa faktor yang dapat menyebabkan pergerakan spermatozoa bergerak mundur dan salah satu pengaruh yang merugikan adalah cekaman dingin (cold-shock) dimana efeknya adalah kematian spermatozoa yang terjadi sesudah thawing, sebagai akibat tingginya daya kontraksi selubung lipoprotein dinding sel. Dengan adanya gliserol dalam pengencer maka efek dari kejutan dingin tersebut dapat meminimalisir kematian spermatozoa. Peranan tris kuning telur dalam pengencer juga berfungsi untuk mempertahankan daya hidup spermatozoa serta sebagai buffer (penyangga) dari perubahan $\mathrm{pH}$ bahan pengencer sedangkan peranan tris dalam pengencer yaitu dapat melindungi spermatozoa dari pengaruh cekaman dingin (cold shock), apabila spermatozoa tersebut memiliki gerakan berayun atau berhenti bergerak maka dianggap mati.

Menurut pendapat Susilawati (2011), kriteria penilaian massa spermatozoa sangat baik (+++) terlihat adanya gelombang besar, banyak, gelap, tebal dan aktif bergerak. Dinilai baik (++) terdapat gelombang-gelombang kecil tipis, jarang, kurang jelas dan bergerak lambat. Dinilai cukup (+), bila tidak terlihat gelombang melainkan gerakan-gerakan individual aktif progresif dan buruk (0), bila tidak ada gerakan sama sekali.

\section{Motilitas Individu Spermatozoa Semen Beku Setelah Thawing}

Dalam motilitas individu pada perlakuan T3 dengan lama thawing 30 detik memberikan nilai tertinggi atau terbaik dalam kualitas semen beku sapi Brahman yaitu dengan nilai 36,88\%, Berdasarkan hasil analisis ragam motilitas individu diketahui bahwa lama waktu thawing menunjukkan pengaruh yang sangat nyata $(\mathrm{P}>0,01)$ terhadap kualitas semen beku Sapi Brahman. Hal ini di sebabkan karena lama waktu thawing dapat memberikan pengaruh terhadap pemeriksaan kualitas motilitas individu spermatozoa yang nantinya akan digunakan untuk Inseminasi Buatan.

Motilitas individu spermatozoa pada perlakuan T3 dengan lama thawing 30 detik memberikan nilai tertinggi atau terbaik dalam kualitas semen beku Sapi Brahman yaitu dengan nilai 36,88\%, sedangkan nilai terendah yaitu pada perlakuan T1 dengan lama thawing 10 detik dengan nilai 17,50\%. Sesuai pendapat Gordon (2002), menyatakan bahwa persentase motilitas 
dan persentase viabilitas spermatozoa tertinggi adalah pada post-thawing dengan suhu $37^{\circ} \mathrm{C}$ selama 30 detik, karena lama waktu thawing 30 detik belum menyebabkan tekanan osmotik yang dapat menyebabkan sel spermatozoa menjadi rusak, sedangkan lama waktu thawing 10 detik menghasilkan motilitas individu terendah hal ini dapat dikatakan terlalu singkat sehingga menyebabkan persentase motilitas spermatozoa rendah karena spermatozoa belum mencair secara sempurna dan lama waktu thawing yang terlalu lama juga dapat menyebabkan spermatozoa banyak yang mengalami kematian.

Menurut Samsudewa dan Suryawijaya (2008), menyatakan bahwa lama thawing yang terlalu lama dan terlalu cepat dapat menyebabkan penurunan motilitas individu sampai pada kualitas yang tidak bisa dipakai lagi untuk Salah satu faktor keberhasilan Inseminasi Buatan. Hal yang paling sering dijadikan pedoman adalah motilitas karena fertilitas juga ditentukan oleh jumlah spermatozoa motil yang bergerak progresif, dan menurut BSN (2005), penentuan nilai harapan 40 juta spermatozoa motil/milliliter ditetapkan berdasarkan ketentuan SNI semen beku sapi yaitu semen yang diinseminasikan memiliki konsentrasi spermatozoa $100 \mathrm{juta} / \mathrm{ml}$ dengan motilitas individu $40 \%$.

\section{Persentase Viabilitas Spermatozoa Semen Beku Setelah Thawing}

Berdasarkan hasil analisis ragam persentase viabilitas diketahui bahwa lama waktu thawing menunjukkan pengaruh yang sangat nyata $(\mathrm{P}>0,01)$ terhadap kualitas semen beku Sapi Brahman. Hal ini di sebabkan karena lama waktu thawing dapat memberikan pengaruh terhadap pemeriksaan kualitas persentase viabilitas spermatozoa yang nantinya akan digunakan untuk Inseminasi Buatan. Persentase viabilitas spermatozoa pada perlakuan T3 dengan lama thawing 30 detik memberikan nilai tertinggi atau terbaik dalam kualitas semen beku Sapi Brahman yaitu dengan nilai 84,50\%, sedangkan nilai terendah yaitu pada perlakuan T1 dengan lama thawing 10 detik dengan nilai 64,38\%. Sesuai dengan pendapat Rodriguez et.al (2005), menyatakan bahwa bahwa proses thawing pada semen beku sapi dengan suhu $37^{0} \mathrm{C}$ selama 60 detik menyebabkan terjadinya beberapa kerusakan pada membran spermatozoa dan lama waktu thawing yang terlalu cepat menyebabkan persentase viabilitas spermatozoa rendah karena spermatozoa belum mencair secara sempurna.

Menurut Sayoko et.al (2007), lama thawing 30 detik memberikan hasil yang lebih baik terhadap persentase viabilitas spermatozoa dari pada thawing selama 15 detik, sperma yang tercat atau berwarna merah berarti sperma itu mati sedangkan yang tidak terwarnai atau tidak 
tercat berarti sperma itu hidup, perubahan warna pada spermatozoa mati disebabkan oleh rusaknya membran plasma pada spermatozoa sehingga zat warna pada eosin terserap oleh spermatozoa tersebut.

Pareira et.al (2010), menyatakan bahwa viabilitas atau persentase hidup spermatozoa semen beku akan menurun akibat suhu dingin selama penyimpanan dalam container, ketersediaan energi dalam pengencer semakin berkurang, dan menurunnya $\mathrm{pH}$ karena terjadi peningkatan asam laktat hasil metabolisme spermatozoa, adanya kerusakan membran plasma dan akrosom, ketersediaan $\mathrm{N} 2$ cair, temperatur selama equilibrasi dalam prosesing pembuatan semen beku, serta handling straw.

\section{Persentase Abnormalitas Spermatozoa Semen Beku Setelah Thawing}

Abnormalitas spermatozoa merupakan penyimpangan morfologi dari kerangka normal spermatozoa. Berdasarkan hasil analisis ragam persentase abnormal diketahui bahwa lama waktu thawing menunjukkan pengaruh yang tidak nyata $(\mathrm{P}<0,01)$ terhadap kualitas semen beku sapi Brahman. Hal ini di sebabkan karena lama waktu thawing tidak dapat memberikan pengaruh terhadap pemeriksaan kualitas persentase abnormal sperma. Persentase abnormal pada perlakuan T5 dengan lama thawing 50 detik memberikan nilai terendah atau terbaik dalam kualitas semen beku sapi Brahman yaitu dengan nilai 8,00 \%, sedangkan nilai tertinggi atau terburuk yaitu pada perlakuan T6 dengan lama thawing 60 detik dengan nilai 10,88\%.

Menurut pendapat (Toelihere, 1981 dalam Ade, Salim et al., 2012), serta (SNI Semen Beku Nasional, 2005) yang merekomendasikan abnormalitas di bawah 20\% masih layak dipakai untuk Inseminasi Buatan. Hal ini mengindikasikan bahwa suhu dan lama thawing pada semua perlakuan belum banyak menyebabkan spermatozoa menjadi abnormal. Penyebabnya karena pada suhu dan durasi thawing pada semua perlakuan belum memberikan tekanan yang ekstrim secara mekanis sehingga spermatozoa menjadi abnormal seperti halnya ciri khas suatu spermatozoa yang mengalami abnormalitas. Salah satu ciri spermatozoa yang mengalami abnormalitas yaitu ekor atau kepalanya yang terputus. Spermatozoa abnormal meningkat selama proses pendinginan dan pembekuan disebabkan oleh cekaman dingin atau cold shock, ketidakseimbangan tekanan osmotik akibat dari proses metabolisme yang terus berlangsung selama penyimpanan.

Menurut pendapat Garner dan Hafez (2008), menyatakan bahwa jika abnormalitas lebih dari $25 \%$ dari satu ejakulat maka penurunan fertilitas tidak dapat diantisipasi. Diperkuat kembali 
oleh Alawiyah (2006), selama abnormalitas spermatozoa belum mencapai $20 \%$ dan tidak lebih dari itu, maka semen tersebut masih layak untuk diproses selanjutnya. Dan menurut Susilawati (2013), menyatakan bahwa pengaruh tingginya abnormalitas berasal dari prossesing penyimpanan dan kondisi fisiologis dari pengencer tersebut, selain itu juga dari faktor pejantan saat penampungan yang berhubungan dengan fertilitas ternak itu sendiri

\section{Konsentrasi Spermatozoa Semen Beku Setelah Thawing}

Berdasarkan hasil penelitian lama waktu thawing terhadap kualitas semen beku sapi Brahman di dapat nilai konsentasi spermatozoa yaitu $53 \times 10^{6}$ juta spermatozoa. Sesuai dengan pendapat BSN (2005), penentuan nilai harapan 40 juta spermatozoa motil/milliliter ditetapkan berdasarkan ketentuan SNI semen beku sapi yaitu semen yang diinseminasikan memiliki konsentrasi spermatozoa $100 \mathrm{juta} / \mathrm{ml}$ dengan motilitas individu $40 \%$.

Menurut Arifiantini (2012), menyatakan bahwa berbagai metoda dapat digunakan untuk menentukan konsentrasi spermatozoa. Penilaian konsentrasi atau jumlah spermatozoa per meliliter semen sangat penting, karena faktor inilah yang menggambarkan sifat-sifat semen dan dipakai sebagai salah satu kriteria penentuan kualitas semen. Konsentrasi digabung dengan volume dan persentase sperma motil memberikan sperma motil per ejakulat yaitu kualitas yang menentukan berapa betina yang dapat di inseminasikan dengan ejakulat tersebut.

Frekuensi ejakulasi di Balai Inseminasi Buatan Sembawa dilakukan satu kali seminggu tentunya frekuensi ejakulasi mempengaruhi konsentrasi spermatozoa. Hal ini sesuai dengan pendapat Ismaya (2014), menyatakan bahwa pejantan yang sering dipakai dengan frekuensi yang tinggi dapat menyebabkan menurunya libido, volume spema, dan konsentrasi sperma. Konsentrasi spermatozoa dipengaruhi oleh perkembangan seksual dan kedewasaan sapi jantan sesuai kualitas makanan yang diberikan dan pengaruh kesehatan reproduksi, peninggian suhu udara karena kelembaban yang tinggi dapat menyebabkan kegagalan pembentukan dan penurunan produksi spermatozoa. Dan menurut Pineda (2003), secara umum volume ejakulat, gerak awal, konsentrasi spermatozoa dan proporsi spermatozoa dipengaruhi oleh musim. Dalam penggunaan straw pada inseminasi buatan dengan jumlah sel sperma yang optimal agar hasil pelaksanaan inseminasi buatan berhasil. Konsentrasi spermatozoa adalah $100 \mathrm{juta} / \mathrm{ml}$ atau 25 juta/dosis straw.

Menurut Feradis (2010), menyatakan bahwa perubahan suhu lingkungan yang tidak menentu akan berpengaruh terhadap organ reproduksi jantan. Fungsi termoregulasi skrotum 
dapat terganggu yang berakibat buruk pada proses spermatogenesis, musim juga berpengaruh terhadap kualitas dan kuantitas semen, peningkatan suhu testis akibat stress dan peningkatan suhu udara karena kelembaban yang tinggi dapat menyebabkan kegagalan dalam pembentukan dan penurunan produksi spermatozoa, secara umum volume ejakulat, motilitas individu dan konsentrasi spermatozoa dipengaruhi oleh musim. Hal ini diduga karena stress akibat dari perubahan cuaca dari musim hujan ke musim kemarau serta meningkatnya suhu lingkungan pada musim kemarau. Hal ini sesuai dengan pernyataan bahwa faktor stres diketahui dapat mempengaruhi volume ejakulat dan konsentrasi spermatozoa.

\section{KESIMPULAN}

Pengaruh lama thawing semen beku Sapi Brahman berpengaruh sangat nyata terhadap Motilitas Individu dan Persentase Viabilitas Spermatozoa. Lama thawing 30 detik pada perlakuan T3 memberikan pengaruh yang sangat baik terhadap kualitas semen beku Sapi Brahman, sedangkan pada lama thawing 50 detik pada perlakuan T5 memberikan kualitas yang baik pada persentase abnormalitas spermatozoa. Nilai konsentrasi spermatozoa semen beku sapi Brahman sebesar $53 \times 10^{6}$.

\section{DAFTAR PUSTAKA}

Ade Salim, Trinil Susilawati dan Sri Wahyuningsih. 2012. Fisiologi Reproduksi pada Ternak. Angkasa. Bandung

Arifiantini. 2012. Teknik koleksi dan evaluasi semen pada hewan. IPB Press. Bogor

Alawiyah. 2006. Abnormalitas Spermatozoa Ternak Sapi. UGM-Press. Yogyakarta

BSN. 2005. Semen Beku Sapi. Badan Standarisasi Nasional. SNI 01-4869.1-2005. BSN. Jakarta

Feradis. 2010. Bioteknologi Reproduksi Pada Ternak. Alfabeta. Bandung.

Gordon. 2002. Controlled Reproduction in Cattle and Buffaloes. CABI Publishing. Wallingford. UK

Garner, D. L. and E. S. E. Hafez. 2008. Spermatozoa and Seminal Plasma in Reproduction in Farm Animals Edited by E. S. E. Hafez. 8 th Ed. Lippincott Wiliams and Wilkins. Philadelphia

Gazali dan Tambing. 2002. Kriopreservasi Sel Spermatozoa. Fakultas Pertanian. Universitas Bandung Raya. Bandung 
Ismaya. 2014. Bioteknologi Inseminasi Buatan Pada Sapi Potong. UGM Press. Yogyakarta

Kaiin, Gunawan, Said dan Tappa. 2005. Peningkatan Ternak Sapi Melalui Teknik Inseminasi Buatan. Teknologi Peternakan dan Veteriner. Bogor

Listiani, D. 2005. Pemberian PGF2 $\alpha$ pada Sapi Peranakan Ongole yang Mengalami Gangguan Korpus Luteum. Tesis. Program Pascasarjana Universitas Diponegoro. Semarang

Pareira, Becker, Siquiera, Severo, Truzzi, and Goncalves. 2010. Assesment Of Bovine Spermatozoa Viability Using Different Cooling Protocols Prior To Cryopreservation. Italian Journal Of Animal Science

Partodiharjo. 1992. Fisiologi Reproduksi Hewan. Mutiara Sumber Widya. IPB. Bogor

Pineda MH. 2003. Male Reproductive System. In Veterinary Endocrinology and Reproduction. $5^{\text {th }}$ Edition. Edited by Pineda MH. And Dooley MP. Ames Blackwell Publishing.

Pramunico, A. 2003.Pengaruh Suhu dan Lama Thawing Semen Beku terhadap Motilitas dan Persentase Spermatozoa Hidup pada Sapi Limousin. Skripsi Sarjana Peternakan. Fakultas Peternakan Universitas Diponegoro, Semarang

Rianto. 2009. Panduan Lengkap Sapi Potong. Cetakan ke-2. Penebar Swadaya. Jakarta

Rodriguez, Almeida,Cuadras, A, Anchondo, Romo - Garcia, B. E., Sanchez, J. A., Jimenez, A. D., Alarcon - Rojo. 2005. Heparin Level Effect on Sperm Capacitation of Fresh an Frozen - Thawed Bovine Semen. Proceedings Vol. 56 . Western Section. American Society of Animal Science. Mexyco City

Salisbury dan Van Demark. 2012. Fisiologi Reproduksi dan Inseminasi Buatan pada Ternak Sapi (Terjemahan R. D januar). UGM Press. Yogyakarta

Samsudewa dan Suryawijaya. 2008. Pengaruh Berbagai Methode Thawing terhadap Kualitas Semen Beku Sapi. Tekhnologi Peternakan dan Veteriner. Fakultas Peternakan. Universitas Diponegoro. Semarang

Sayoko, Hartono, dan Silotonga. 2007. Faktor-faktor yang Mempengaruhi Persentase Spermatozoa Hidup Semen Beku Sapi pada Berbagai Inseminator di Lampung Tengah. Fakultas Pertanian. Universitas Lampung. Lampung

Sumeidiana. 2007. Volume Semen dan Konsentrasi Sperma Ternak Sapi Potong. Fakultas Pertanian. Universitas Lampung. Lampung

Situmorang. 2002. The Effects of Inclusion of Exogenous Phospolipid In Tris-Diluent Containing A Different Level of Egg Yolk on the Viability of Bull Spermatozoa. Pusat Penelitian dan Pengembangan Peternakan dan Badan Penelitian dan Pengembangan Pertanian, Bogor 7 (3) : 131-187.23 <SNI> Standar Nasional Indonesia. 2005. Standar Nasional Indonesia Semen Beku Sapi. Badan Standar Nasional. Jakarta

Susilawati. 2011. Spermatology. Universitas Brawijaya Press. Malang

Susilawati. 2013. Pedoman Inseminasi Buatan Pada Ternak. Universitas Brawijaya (UB) Press. Malang 
| JURNAL PETERNAKAN | VOLUME : 03 | NO : 02 | TAHUN 2019 | E-ISSN. 2599-1736|78

SNI. (Standar Nasional Indonesia). 2005. Standar Nasional Indonesia Semen Beku Sapi. Badan Standar Nasional. Jakarta

SNI (Standar Nasional Indonesia). 2008. Semen Beku - Bagian 1 : Sapi (SNI 4869.1:2008). BSN (Badan Standarisasi Nasional). Jakarta

UPTD BIB Sembawa. 2002. Standar Operasional Prosedur UPTD BIB Sembawa. Dirjen Peternakan Departemen Pertanian. Sumatera Selatan

Warsito dan Andoko. 2012. Karakteristik Ternak Sapi Brahman. Universitas Brawijaya Press. Malang 